\title{
V. SOLODOV
}

\section{IMPROVEMENT OF STEAM INLET OF THE HIGH PRESSURE CYLINDER FOR K-220-44-2 TURBINE OF THE LOVIISA NPP}

A model for calculating the viscous flow of steam through a conical perforated steam sieve is proposed. The model takes into account the complex geometry of the channels, the results of design and engineering developments and computational studies to optimize the stop valves of the steam line for flow path of the high-pressure cylinder of the K-220-44-2 turbine for the Loviisa NPP are considered (Finland). The main attention during the modernization of stop valves 1 and 2 was paid to the problem of reducing losses on the steam sieve. A number of design features largely offset the effect of a large number of holes. These include the flow around the perforated surface at an angle to the axis of the holes; obstruction of the steam line channel behind the side surface of the steam sieve with three longitudinal ribs, as well as by an annular zone without holes at the junction of the side and bottom surfaces. During modernization the inner diameter of the inlet part of the body in casting was increased, which made it possible to increase the free cross-section of the perforated steam sieve. The proposed design solutions were investigated numerically. The spatial three-dimensional flow of a viscous compressible steam through the flow path was analyzed by numerically integrating the system of Navier-Stokes equations averaged by Reynolds-Favre. The system was supplemented with equations of the differential turbulence model. The integration of the system of Navier-Stokes equations and associated equations was carried out using the author's software package. The calculated subdomains were approximated by unstructured hexahedral meshes. The solver used an implicit difference scheme of finite volumes of the 2nd order of accuracy and a variant of the algorithm that allows efficient splitting of the computational process for multiprocessor platforms. The solid walls were assumed to be adiabatic, the no-slip condition and the equality of effective vortex viscosity to zero were set on them. Turbulent effects were described based on the Menter model and the modified Spalart-Allmaras turbulence model.

Keywords: nuclear power plant, turbine, check valve, steam, numerical simulation, velocity, pressure loss.

\section{В. Г. СОЛОДОВ}

\section{ВДОСКОНАЛЕННЯ ПАРОВПУСКУ ТУРБИНИ К-220-44-2М АЕС «ЛОВІІА»}

Запропоновано модель в'язкого перебігу пари через конічне перфороване парове сито. Модель враховує складну геометрію каналів, результати розробок та розрахункових досліджень щодо оптимізації запірної арматури паропроводу проточної частини циліндра високого тиску турбіни К-220-44-2 для АЕС Ловіїса (Фінляндія). Основну увагу при модернізації запірної арматури було приділено проблемі зниження втрат на паровому ситі. Ряд конструктивних особливостей багато в чому компенсує ефект великої кількості отворів. До них відносяться обтікання перфорованої поверхні під кутом осі отворів; захаращення каналу паропроводу за бічною поверхнею парового сита трьома поздовжніми ребрами, а також кільцевою зоною без отворів на стику бічної та нижньої поверхонь. У ході модернізації було збільшено внутрішній діаметр вхідної частини корпусу, що дозволило збільшити прохідний переріз перфорованого парового сита. Запропоновані конструктивні рішення досліджено чисельно. Просторовий тривимірний потік в'язкої пари, що стискається, проаналізований шляхом чисельного інтегрування системи рівнянь Навье-Стокса, усереднених по Рейнольдсу-Фавру. Система доповнена рівняннями диференціальної моделі турбулентності. Інтегрування проводилося за допомогою авторського пакета програм. Розрахункові підобласті апроксимувалися неструктурованими гексаедричними сітками. При вирішенні використовувалася неявна різницева схема кінцевих обсягів 2-го порядку точності та варіант алгоритму, що дозволяє ефективно розділити обчислювальний процес для багатопроцесорних платформ. Тверді стінки вважалися адіабатичними, на них ставилися умова прилипання та рівність ефективної вихрової в'язкості нулю. Турбулентні ефекти описувалися з урахуванням моделі Ментера і модифікованої моделі турбулентності Спаларта-Аллмараса.

Ключові слова: атомна електростанція, турбіна, зворотний клапан, пара, чисельне моделювання, швидкість, втрата тиску.

\section{в. Г. СОЛОдОв}

\section{СОВЕРШЕНСТВОВАНИЕ ПАРОВПУСКА ТУРБИНЫ К-220-44-2М АЭС «ЛОВИИСА»}

Предложена модель вязкого течения пара через коническое перфорированное паровое сито. Модель учитывает сложную геометрию каналов, результаты разработок и расчетных исследований по оптимизации запорной арматуры паропровода проточной части цилиндра высокого давления турбины К-220-44-2 для АЭС Ловииса (Финляндия). Основное внимание при модернизации запорной арматуры было уделено проблеме снижения потерь на паровом сите. Ряд конструктивных особенностей во многом компенсирует эффект большого количества отверстий. К ним относятся обтекание перфорированной поверхности под углом к оси отверстий; загромождение канала паропровода за боковой поверхностью парового сита тремя продольными ребрами, а также кольцевой зоной без отверстий на стыке боковой и нижней поверхностей. В ходе модернизации был увеличен внутренний диаметр входной части корпуса, что позволило увеличить проходное сечение перфорированного парового сита. Предложенные конструктивные решения исследованы численно. Пространственный трехмерный поток вязкого сжимаемого пара проанализирован путем численного интегрирования системы уравнений Навье-Стокса, усредненных по РейнольдсуФавру. Система дополнена уравнениями дифференциальной модели турбулентности. Интегрирование проводилось с использованием авторского пакета программ. Расчетные подобласти аппроксимировались неструктурированными гексаэдрическими сетками. При решении использовалась неявная разностная схема конечных объемов 2-го порядка точности и вариант алгоритма, позволяющий эффективно разделить вычислительный процесс для многопроцессорных платформ. Твердые стенки считались адиабатическими, на них ставились условие прилипания и равенство эффективной вихревой вязкости нулю. Турбулентные эффекты описывались на основе модели Ментера и модифицированной модели турбулентности Спаларта-Аллмараса.

Ключевые слова: атомная электростанция, турбина, обратный клапан, пар, численное моделирование, скорость, потеря давления.

Introduction. The nuclear power plant of the Loviisa NPP in Finland is equipped with four turbines of the second modernization K-220-44-2 [1, 2], commissioned until 1980. The article discusses the solution to the problem of improving the technical and economic indicators of a turbine plant, which consists in reducing the pressure loss in the steam inlet path by reducing the resistance of steam sieves in the check 
valves.

Improvement of the steam inlet tract. The steam inlet line of the K-220-44-2 turbine (Fig. 1, 2) includes two check valves 1 and two check valves 2 with steam sieves 3 and upstream steam lines 4 and 5 , bypass steam lines 6 and 7, two control valves 8 and 9 connected to the inlet pipe 10 of the first stage.

All elements of the steam admission path, except for the check valves, have the original design. Control valves 8 and 9 are considered in the work as elements of influence on the characteristics of stop valves.

The flow paths of steam for the four check valves from the inlet section of the steam sieve to the outlet section of the seat are practically the same. Thus, the flow parts of the stop valves 1 and 2 differ only in the shape of the channels from the live steam line to the plane of the inlet section of the steam sieve and in the angle of the bend behind the seat.

Perforated steam sieve has the shape of a truncated cone and contains cylindrical channels with a diameter of $5 \mathrm{~mm}$ : 8190 channels on the side surface and 555 channels on the bottom surface with a total area of 1,2 times the inlet area. The holes in the steam sieve are made with a $0,4 \times 45^{\circ}$ chamfer at the inlet, the center-to-center distances are $7 \mathrm{~mm}$. A number of design features largely offset the effect of a large number of holes. These include the flow around the perforated surface at an angle to the axis of the holes; obstruction of the steam line channel behind the side surface of the substation with three longitudinal ribs with a thickness of $16 \mathrm{~mm}$, as well as an annular zone without holes with a total width of $47,5 \mathrm{~mm}$ at the junction of the side and bottom surfaces.

Therefore, the main attention during the modernization of stop valves 1 and 2 is paid to the problem of reducing losses on the steam sieve. To solve it, the inner diameter of the inlet part of the body in casting was increased from $450 \mathrm{~mm}$ to $600 \mathrm{~mm}$, i. e. to the inner diameter of the upper part of the original body, which made it possible to increase the free cross-section of the perforated steam sieve.

The proposed design solutions were simulated and investigated numerically. A method was used to solve the direct problem of the spatial three-dimensional flow of a viscous compressible gas through the flow path by numerically integrating the system of Navier-Stokes equations averaged over Reynolds-Favre [3]. The system was supplemented with equations of the differential turbulence model. The integration of the system of NavierStokes equations and associated equations was carried out using the software package [4-6]. The calculated subdomains were approximated by unstructured hexahedral meshes. The solver used an implicit difference scheme of finite volumes of the 2nd order of accuracy and a variant of the algorithm $[5,6]$ that allows efficient splitting of the computational process for multiprocessor platforms. The solid walls were assumed to be adiabatic, the no-slip condition and the equality of effective vortex viscosity to zero were set on them. Turbulent effects were described based on the Menter model [5] and the modified Spalart-Allmaras turbulence model [6].

The existing steam sieve is a complex element from the point of view of gas dynamic calculations. To overcome the difficulties in calculating the flow around the sieve in order to save computing resources, a symmetric fragment was allocated and a sector approach was applied $[4,5]$. The capacities of the grid division by the elements of the path varied from 5-8 million cells in the flow part of the valves to 30 million cells in the models of steam sieves. At the first stage of research, the objects were modeled in an isolated setting, then - under the conditions of mutual influence of sieves, stop and control valves.

Numerical simulation of the flow in the steam sieve variants was carried out in the absence of the possibility of experimental verification of the results obtained.

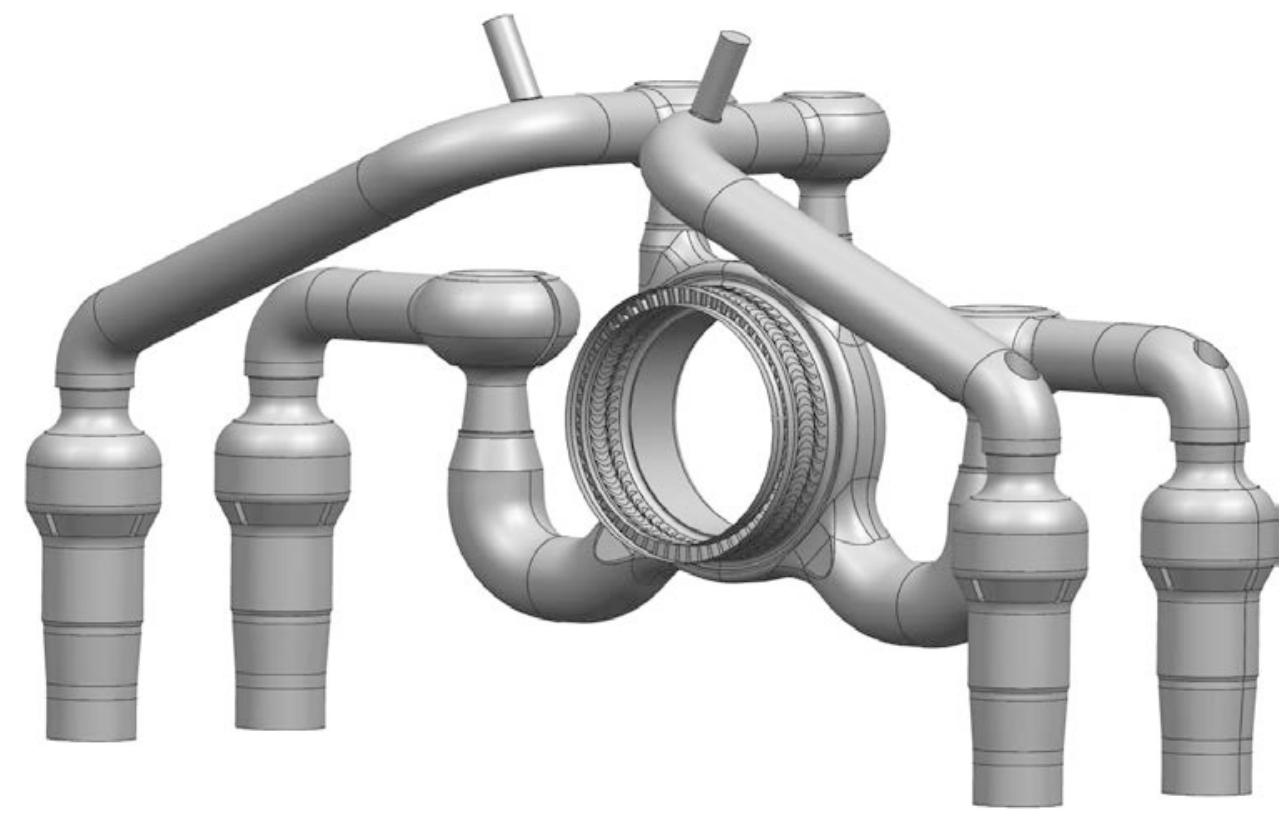

Fig. 1. Model of the original steam inlet and check valve options

Bulletin of the National Technical University "KhPI".

Series: Hydraulic machines and hydraulic units, no. 2'2021 


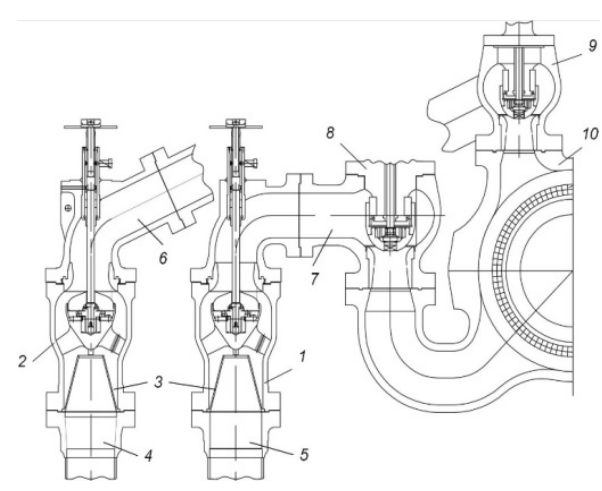

Fig. 2. Scheme of the original steam inlet tract of the turbine

Therefore, the calculation strategy was based on the preliminary selection of the computational grid for the flow through a single initial hole and a profiled hole with a tapered chamfer at the inlet, a cylindrical section with a diameter of $5 \mathrm{~mm}$ and with a diffuser with a central angle of 8 degrees, the calculated data for which were compared with known experimental data [7]. The grid parameters selected in this way were used to simulate the flow for a symmetric fragment of a real steam sieve. Based on this computational technology, a detailed gas-dynamic analysis of losses on sieves of various configurations and with different shapes of holes has been carried out. The analyzed configurations were subjected to strength analysis for the parameters of the K-220-44-2 turbine.

The upgraded stop valve 1 with a flat steam sieve is shown in Fig. 2, 3 and differs from the original valve in such new elements as: an upstream extended steam line with a diffuser channel, which provides minimal technological cutting of live steam lines, a valve body, a flat steam sieve with profiled holes, profiled ribs - fairing supports, valve cup and valve seat.

According to the results of computational studies, it was found that the losses on the steam sieve in the original check valves amount to $72 \%$ of the total pressure loss, and the losses in the valves themselves are concentrated mainly in the sections of the channel in front of and behind the valve seat. Therefore, the main focus was on improving the steam sieve.

The detailed studies of the gas-dynamic and energy parameters of steam sieves of the original and flat modifications have shown that flat sieves with profiled holes are the best $[8,9]$. Thus, the use of a flat steam sieve with profiled holes in the amount of 3640 pieces reduced the losses in the original check valve by 2 times.

Studies of check valves with the modernization of the bodies by increasing the diameter of the inlet part confirmed the advantages of flat steam sieves: the installation of a sieve with the original shape of the holes provided a decrease in losses in relation to the original version by $62 \%$. The best results were obtained with a redesigned valve with a flat screen, perforated profiled holes, and new valve cup and seat shapes.

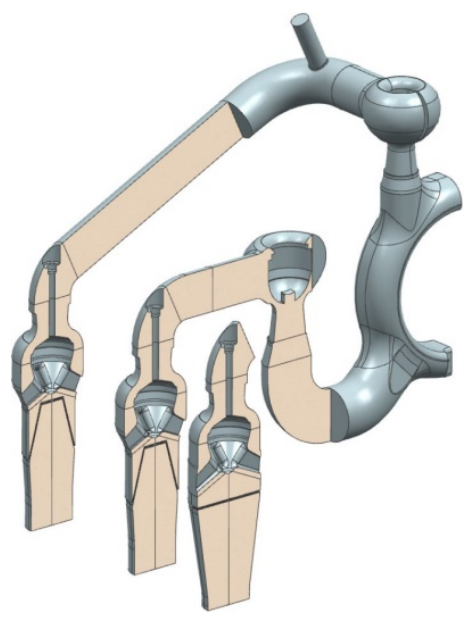

Fig. 3. Model of the steam inlet and check valve options

Fig. 4 shows the velocity fields in the original check valve with a sieve and in the upgraded second version. The graphs of the total pressure loss along the flow path of the indicated check valves are given in Fig. 5. The loss factor is defined as the difference in total pressures between the inlet and in the design section of the bypass steam line, referred to the velocity head at the inlet.

A detailed comparison of the components of losses in the original and modernized valves showed that the main effect is achieved by improving the steam sieve and increasing its diameter. At the same time, the profiling of the sieve holes reduces the losses on the sieve by 2,8 times. Improving the shape of the channel formed by the valve cup and seat reduces valve losses by $20 \%$.

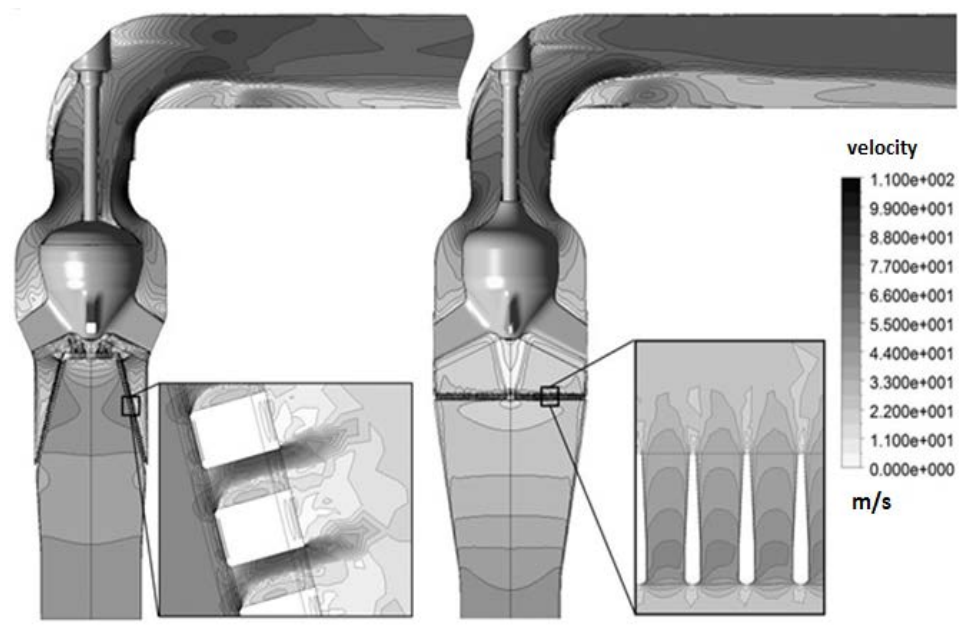

Fig. 4. Velocity fields for original and upgraded valve 


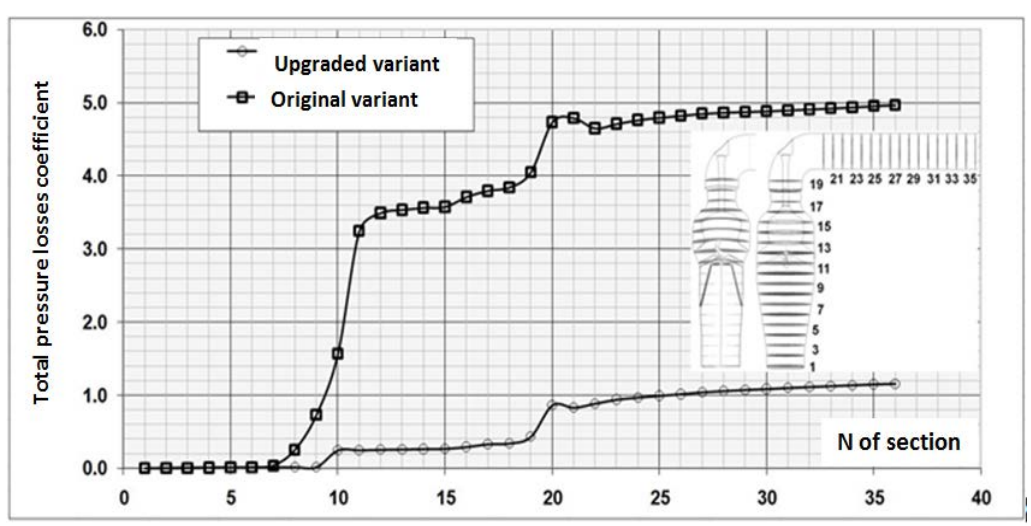

Fig. 5. Total pressure loss for original and upgraded valves

Conclusion. Design solutions, along with threedimensional modeling, made it possible to increase the efficiency of the existing version of the flow path of the steam inlet, and to simplify the technology of manufacturing steam sieves.

\section{References}

1. Швецов В. Л. Опыт ОАО «Турбоатом» в создании и совершенствовании энергосберегающего оборудования для тепловых и атомных электростанций. Вісник Нац. техн. ун-та «ХII». Сер.: Енергетичні $i$ теплотехнічні прочеси $i$ устаткування. Харків: НТУ «ХПІ». 2006. № 5. С. 6-11.

2. Левченко Е. В., Галацан В. Н., Аркадьев Б. А.,, Сухинин В. П., Потапов А. Н., Швецов В. Л. Модернизация турбин НПО «Турбоатом» мощностью 20МВт для АЭС. Теплоэнергетика 1997. № 7. С. 6-12.

3. Солодов В. Г. Моделирование турбулентных течений: расчет больиих вихрей. Харьков: ХНАДУ, 2011. 168 с.

4. Солодов В. Г., Стародубцев Ю. В. Сертификат гос. регистр. авт. прав УГААСП № 5921. Научно-прикладной программный комплекс МTFS ${ }^{\circledR}$ дл расчета трехмерных вязких турбулентных течений жидкостей $и$ газов в областях произвольной формыл. 2002.

5. Солодов В.Г., Стародубцев Ю. В. Опыт моделирования сжимаемых вязких турбулентных течений во входных и выходных устройствах турбомашин. Проблемы машиностроения. 2002. Т. 5, № 1. С. 29-38.

6. Солодов В.Г., Стародубцев Ю. В. Опыт трехмерного моделирования сжимаемых вязких турбулентных течений в турбомашинах. Аэрогидродинамика: Проблемы и перспективы. Харьков: «ХАИ», 2004. С. 134-157.

7. Идельчик И. Е. Справочник по гидравлическим сопротивлениям. Москва: Машиностроение, 1992. 672 с.

8. Солодов В. Г., Х Хандримайлов А. А., Швецов В. Л. Кожешкурт И. И., Конев В. А. Исследование аэродинамических и энергетических характеристик отсека ступеней с патрубком паровпуска ЦНД мощной паровой турбины с учётом протечек. Вісник Нац. техн. ун-ту «ХПI». Сер.: Енергетичні та теплотехнічні прочеси й устаткування. Харків: НТУ «ХПІ». 2016. № 8 (1180). C. 6-15. doi: 10.20998/2078-774X.2016.08.01

9. Шубенко А. Л., Швецов В. Л., Голощапов В. Н., Солодов В. Г., Алехина С. В. Совериенствование термо-газодинамических характеристик проточных частей мощзых паровых турбин. Харьков: Цифрова друкарня № 1, 2013. 172 с.

\section{References (transliterated)}

1. Shvetsov V. L. Opyt OAO "Turboatom" v sozdanii i sovershenstvovanii energosberegayushchego oborudovaniya dlya teplovykh i atomnykh elektrostantsiy [Experience of JSC "Turboatom" in developing and improving of energy-saving equipment for thermal and nuclear power plants]. Visnyk Nats. tekhn. un-ta "KhPI". Seriya: Enerhetychni i teplotekhnichni protsesy $i$ ustatkuvannya [Bulletin of the National Technical University "KhPI". Series: Energy and heat engineering processes and equipment]. Kharkiv, NTU "KhPI" Publ., 2006, no. 5, pp. 6-11.

2. Levchenko E. V., Galatsan V. N., Arkad'ev B. A., Sukhinin V. P. Potapov A. N., Shvetsov V. L. Modernizatsiya turbin NPO «Turboatom» moshchnost'yu 20MVt dlya AES [Modernization of turbines NPO "Turboatom" with a capacity of 220 MW for nuclear power plants]. Teploenergetika. 1997, no. 7, pp. 6-12.

3. Solodov V. G. Modelirovanie turbulentnykh techeniy: raschet bol'shikh vikhrey [Turbulent flow modeling. Large eddy simulation] Kharkov, KhNADU Publ., 2011. 168 p.

4. Solodov V. G., Starodubtsev Yu. V. Nauchno-prikladnoy programmnyy kompleks MTFS ${ }^{\circledR}$ dlya rascheta trekhmernykh vyazkikh turbulentnykh techeniy zhidkostey $i$ gazov $v$ oblastyakh proizvol'noy formy [Scientific Application Software MTFS ${ }^{\circledR}$ for Calculation of 3D Viscous Turbulent Flows of Liquids and Gases in the Regions of Arbitrary Form]. Patent UGAASP, no. 5921, 2002.

5. Solodov V. G., Starodubtsev Yu. V. Opyt modelirovaniya szhimaemykh vyazkikh turbulentnykh techeniy vo vkhodnykh i vykhodnykh ustroystvakh turbomashin [Experience in modeling compressible viscous turbulent flows in the input and output devices of turbomachines]. Problemy mashinostroeniya. 2002, vol. 5, no. 1, pp. 29-38.

6. Solodov V. G., Starodubtsev Yu. V. Opyt trekhmernogo modelirovaniya szhimaemykh vyazkikh turbulentnykh techeniy $\mathrm{v}$ turbomashinakh [The experience of 3D modeling of compressible viscous turbulent flows in turbomachinery]. Aerogidrodinamika: Problemy i perspektivy [Aerohydrodynamics: Problems and Prospects]. Kharkov, "KhAI" Publ., 2004, pp. 134-157.

7. Idel'chik I. E. Spravochnik po gidravlicheskim soprotivleniyam [Handbook of hydraulic resistance]. Moscow, Mashinostroenie Publ., 1992. 672 p.

8. Solodov V. G., Khandrimaylov A. A., Shvetsov V. L., Kozheshkurt I. I., Konev V. A. Issledovanie aerodinamicheskikh i energeticheskikh kharakteristik otseka stupeney $\mathrm{s}$ patrubkom parovpuska TsND moshchnoy parovoy turbiny s uchetom protechek [Investigation of aerodynamic and energy characteristics of L.P.C. compartment of stages with inlet pipe and leak system for powerful steam turbine unit]. Visnyk Nats, tekhn. un-tu «KhPI». Seriya: Enerhetychni ta teplotekhnichni protsesy y ustatkuvannya [Bulletin of the National Technical University "KhPI". Series: Power and heat engineering processes and equipment]. Kharkiv, NTU "KhPI" Publ., 201, no. 8 (1180), pp. 6-15. doi: 10.20998/2078-774X.2016.08.01

9. Shubenko A. L., Shvetsov V. L., Goloshchapov V. N., Solodov V. G., Alekhina S. V. Sovershenstvovanie termogazodinamicheskikh kharakteristik protochnykh chastey moshchnykh parovykh turbin [An improvement of thermo- and gas dynamic characteristics of flow path of power steam turbine units]. Kharkov, Tsifrova drukarnya no. 1 Publ., 2013. 172 p.

Received 17.11.2021

\section{Відомості про авторів / Сведения об авторах / About the Authors}

Солодов Валерій Григорович (Солодов Валерий Григорьевич, Solodov Valerii) - доктор технічних наук, професор, Харківський національний автомобільно-дорожній університет, завідувач кафедри «Теоретична механіка та гідравліка»; м. Харків, Україна; ORCID: https://orcid.org/0000-0001-9607-8184; e-mail: solodov.v@gmail.com

Bulletin of the National Technical University "KhPI".

Series: Hydraulic machines and hydraulic units, no. 2'2021 